\title{
A Multidimensional Subjective Scale Development for Measuring Sales Performance of Retail Sales Personnel
}

\author{
M.M.Munshi ${ }^{1}$, Sanjay Hanji ${ }^{2}$ \\ ${ }^{1}$ Associate Professor, Department of Post Graduate Studies, Visvesvaraya Technological University, "Jnana \\ Sangama”, Belgaum-590 018, Karnataka, India. \\ ${ }^{2}$ Research Scholar, Department of Management Studies and Research, Gogte Institute of Technology, \\ Udyambag, Belgaum, and working as Associate Professor, Department of Management Studies, Basaveshwar \\ Engineering College, Vidyagiri, Bagalkot-587102, Karnataka, India.
}

\begin{abstract}
In retail stores, salespeople are the main point of contact for customers and they are responsible for communication, store management, sales activities, solving customers' problems, helping them to make purchase decisions and thereby realizing sales closures and generating sales revenues. For that reason, evaluating sales performance of retail salespeople becomes a bit of problem to sales managers and researchers. Therefore, one of the most difficult tasks for sales managers is evaluating the performance of sales people under their control (Damnjanovic and Kulj, 2005). This study aims at developing a holistic measurement scale to evaluate sales performance of retail salespeople. Thorough analysis of literature and depth interviews with salespeople and sales managers at retail stores provided 48 different job related tasks which seemingly acted as indicators of sales force performance. These 48 items were subjected to Exploratory Factor Analysis (EFA) technique using SPSS 16 Version Processor with a purpose of removing unrelated and insignificant items thereby converging them into some meaningful factors. The final scale derived has 23 items converged into five underlying factors namely, Customer Service, Sales Enhancement Ability, Store Management Ability, Product Knowledge and Presentation, and Team Work. These factors represent the dimensions of sales performance measurement scale.
\end{abstract}

Keywords: Sales People, Sales Performance Evaluation, Retail Stores, Scale Development.

\section{Introduction}

An understanding of the dimensions of sales performance which indicate performance level of each salesperson is essential for both managers and researchers in sales and marketing. Sales managers and researchers have always tried to understand the perfect indicators of sales performance.

(Damnjanovic, V., and Kulj, D., 2005) believe that, according to method of evaluation, there are two types of criteria: qualitative and quantitative performance criteria. Quantitative criteria are numeric and they relate to number of new customer obtained, sales volume, average sales calls per day, gross profit by product/customer, sales orders. Many organizations use qualitative performance criteria because they represent the salesperson's major job activities, and they indicate why the quantitative measures look as they do. Qualitative performance criteria are characteristics, behavior or results of salesperson which cannot be expressed in numbers and the quality of these criteria may depend on subjective evaluation of reviewer.

Proper performance evaluation begins with the development of the proper criteria. Performance criteria should be measurable, practical, relevant, discriminating, and stable and should encompass both results and activities (Futrell, 1998). Here results are quantitative or objective and are provided by the company but the activities what salespeople perform are qualitative or subjective and are not provided by the company where salespeople have to be evaluated for sales performance. The quantitative results what salespeople achieve are the results of all the sales job activities done by retail sales force. Hence using only quantitative measures to evaluate sales force performance in retail store will not give holistic picture of their sales performance.

\section{Literature Review}

The sales force's performance measurement in marketing has been an important topic (Pilling et al., 1999). Performance is a multidimensional construct, the measurement of which varies and it depends on a variety of factors that comprise it (Fitzgerald and Moon, 1996).

Sales performance is often described as the quality and quantity of sales closed in a specific time period (Salleh and Kamaruddin, 2011).

Ahmad et al., (2012), defined sales performance as any company that sells products to customers uses a form of sales performance measurement to evaluate an employee's quality of work and help pinpoint development areas. The sales management literature provides and shows numerous illustrations of different factors and models that have influence of evaluation the salespersons (Futrell, 1998). 
Many scholars have linked to sales performance to many different indicators such as profit rate; some use sales volume; and some link it with productivity (Porter, 1985) to define the meaning of sales performance.

Kohli and Jaworski (1994) studied influence of co-worker feedback on sales force performance. They measured sales force performance in terms of profitability, growth and sales volume.

In the study conducted by Pettijohn et al., (2000), performance of sale people was measured by a scale which included: (a) Relative ranking: the salesperson's performance ranking relative to others in the store; (b) Sales volume: the percentage of store's total sales volume generated by the salesperson; (c) Closing ratio: the salesperson's of successfully closed sales to the number of sales contacts. The sales managers provided ratings of their salesperson's performance.

In the study conducted by Plouffe, Sridharan, and Barclay, (2010), they have adopted two formative indicators of sales performance: one an objective measure provided by each firm's management; the other a subjective, salesperson-reported measure. The objective performance measures were provided by each firm's management. The self report subject measure of sales performance was adopted from Johlke et al., (2000) which is reported to be being modeled on the popular scale Behrman and Perreault (1982). This scale has 11-point Likert scale (where the salesperson rates themselves from -5 much worse than the other salespeople in this company\} to 'average' to +5 \{much better than the other salespeople in this company\}). The six self-reported measures of performance were summed into a single composite measure of subjective performance.

Abelson, Kacmar, and Jackofsky, (1990), in an effort to determine the factors influencing real estate brokerage sales staff performance, have used sales commission earned by sales staff as a measure to evaluate their sales performance in real estate industry. For analyses, an adjusted daily average earned was calculated.

Samad and Jainullabdeen made an attempt to examine the improvement in sales performance from sales force by their adaptive selling behavior; customer oriented selling, \& job characteristics. Sales performance measures were taken from the job description. It consisted of two questions, target based sales performance and valuewise sales performance.

John, Francis, Innocent (2012), explored improvement in sales performance from their sales force motivation strategy. The sales performance of sales people is evaluated using profitability and sales growth of individual sales people. The results show a strong relationship between the dimensions of the motivation strategy and sales performance.

For successful salespeople Colletti and Tubridy (1993) has provided the following list of sales activities namely, selling, working with distributors, entertainment, attending meetings, servicing products, working with orders, servicing accounts, travel, communication/information, training and recruiting.

Ten other set of criteria cited by Campbell (1990) are sales volume and ability to reach quotas, customer relations and management of expense accounts, company knowledge and customer knowledge, product knowledge and competitor knowledge and time management and planning that are important for sales performance. Four primarily objective performance criteria can be framed using the above checklist; such as annual sales volume, gross profit per sale, annual sales volume and profit, and growth in customer relations.

Salleh and Kamaruddin (2011), studied the effects of personality factors on sales performance of insurance agents in Malaysia. They measured sales performance by the annual earnings of salesperson which included bonuses and commissions.

Ma, Yu and Cheng (2013), conducted a study to understand the impacts of salesmen personality traits and the learning effects on the results of sales performance. In this study sales performance indicators of sales people consisted of questions such as, subjective self assessment over the past three months on the amount of total sales, total commission earned, and total sales combined with the organizational level of performance such as changes in relative market share, return on investment and the success of newly launched products. Each of these questions adopted a five point Likert scales with higher scores indicating better performance.

Komaran and Ching (1997) believe that selling entails a variety of tasks, sequential steps and personal attributes, therefore, sales performance assessments should take into account different objective and subjective variables. Hence they have classified salesperson's performance evaluation criteria into two types' i.e., objective measures and subjective measures. The objective measurements consists of three sub classifications: (a) quantitative output measures (ex: sales volume, number of orders net profit etc.), (b) quantitative input measures (ex: number of calls, days worked, service calls made etc.), (c) ratios of input \& output measures (ex: calls per day, order per call, cost per call etc.). The subjective measurement consists of qualitative measures (ex: product knowledge, customer knowledge, attitude etc.).

Chonko et al., (2000) investigated how time of measurement and types of variable used to measure sales performance can impact the results of sales performance studies. Mainly two different measures of sales performance were examined. (a) Company Records provided the management evaluations of salesperson performance which included sales volume, sales vs. quota, number of sales calls made etc. (b) Self Report Performance measure which included ten criteria such as sales volume, ability to reach quotas, customer relations, expense accounts, company knowledge, customer knowledge, product knowledge, time management, and planning. 
Behrman et al., (1982) developed a scale to measure the job performance of industrial salespeople. It consisted of 31 items that represent five components namely, (a) sales presentation, (b) providing information, (c) technical knowledge, (d) sales objective, and (e) controlling expenses. This instrument does not evaluate retail salesperson's sales performance.

Bush et al., (1990) have developed a scale to measure retail salesperson performance. The construct's domain was defined as consisting of five behaviour-based factors: (a) knowledge of merchandise procedures, (b) customer service ability, (c) sales ability, (d) product-merchandise knowledge, and (e) knowledge of store policy. This scale consists of 22 items and it evaluates the job performance of retail sales people but it does not evaluate sales performance or justify that it measures sales performance of retail sales people. Secondly the scale was developed two decades ago and today retailing has changed and so the applicability of the scale is also questionable. However, the underlying dimensions of the scale are note worthy.

\section{Statement Of The Problem}

The appropriate way to measure sales performance has been debated extensively in the literature. The above literature indicates a gap in appropriate measurement scale to measure sales performance of retail sales people. A great unresolved controversy in sales management is whether output measures, input factors or qualitative criteria are best for evaluating sales performance (Dalrymple et al., 2004). Also in retail stores, salespeople are the main point of contact for customers and they are responsible for communication, store management, sales activities, solving customers' problems, helping them to make purchase decisions and thereby realizing sales closures and generating sales revenues. The objective or outcome based indicators of sales performance such as sales volume, sales revenue, sales closures are the outcomes of variety of tasks and sequential steps of sales person in retail store and hence only considering objective based indicators of sales performance will not provide complete information about sales force performance. For that reason, evaluation of retail sales force performance requires a multidimensional and a multi-variate measurement scale. Hence this study makes an attempt to fill this research gap by developing a multidimensional subjective scale to measure sales performance of retail sales force. First, this research takes into account exclusive list of various tasks and duties of retail sales force which seemingly indicate their sales performance and later through factor analysis it identifies among them the important indicators of sales performance of retail sales people. It also finds underlying dimensions or factors for the same.

\section{Objectives Of The Study}

To main objective of the study is to determine the underlying factors or dimensions of retail sales performance and to arrive at a subjective scale to measure sales performance of retail sales people.

\section{Research Methodology}

At the initial stage of the study, depth interviews were conducted on sales people and sales managers at various organized retail stores and few big unorganized retail stores to understand various important duties and tasks carried out by sales people which were also used as key indicators by sales managers or HR professionals to assess the sales performance of retail sales people. Extensive literature reviews revealed some key variables which could be used as key indicators. Overall, through depth interviews and literature reviews, an exclusive list of 48 different tasks and duties relating to retail sales people were identified which seemingly predict and indicate their sales performance. To further refine these 48 variables, factor analysis was performed.

Factor analysis is an interdependence technique, whose primary purpose is to define the underlying structure among the variables in the analysis. It provides the tools for analyzing the structure of the interrelationships (correlations) among a large number of variables (e.g., test score, test items, questionnaire responses) by defining sets of variables that are highly interrelated, known as factors (Hair et al, 2006). It is a very useful method of reducing data complexity by reducing the number of variables being studied (Nargundkar, 2008).

\section{Sampling:}

The stratified sampling technique was used for the study. The sample consisted of sales people and sales managers from different of retail formats (such as as Hypermarkets, Specialty stores, Convenience stores and Super-markets) from various districts of north Karnataka, India. The districts of north Karnataka, considered for the study were, namely, Bagalkot, Belgaum, Dharwad-Hubli, and Bijapur. As a general rule of sample size for factor analysis, the minimum is to have at least five times as many observations as the number of variables to be analyzed (Hair et al, 2006). For this study, 48 different variables or items were taken for analysis and the sample size chosen for the study was 300 sales people which are more than 5 times of the variables. Out of 300 samples chosen only 280 responded which is $93.3 \%$ of total response rate. 


\section{Questionnaire Development:}

A well-structured questionnaire was developed for the study. Totally 48 variables or items (tasks and duties of sales people) were listed out in the questionnaires which were possible indicators of their sales performance. The sales people from different retail stores were asked to assess the importance of all the 48 variables based on their experience which they feel that they act as key indicators of their sales performance. A five point scale was used where the ratings ranged from 1 to 5 and " 1 " is used to rate "Not at all Important" and "5" is used to rate "Very Important".

\section{KMO and Bartlett's Test:}

\section{Data Analysis And Interpretation}

The Kaiser-Meyer-Olkin (KMO) measure of sampling adequacy is an index used to examine the appropriateness of factor analysis. This index ranges from 0 to 1 . High values (from 0.5 to 1.0) indicate factor analysis is appropriate (Malhotra and Dash, 2007). The value which is equal to 0.80 or above is considered as meritorious (Hair et al 2006). From table 1, the Kaiser-Meyer-Olkin Measure of Sampling Adequacy is 0.827 which is meritorious result for the study. The Bartlett's Test of Sphericity from table 1, the sig value is 0.000 which is significant at $95 \%$ confidence level. A statistically significant Bartlett's test of sphericity indicates that sufficient correlations exist among the variables to proceed with factor analysis (Hair et al, 2006).

\begin{tabular}{|c|c|c|}
\hline \multicolumn{3}{|c|}{ Table: 1 KMO and Bartlett's Test } \\
\hline Kaiser-Meyer-Olkin Measur & lequacy & .827 \\
\hline Bartlett's Test of Sphericity & $\begin{array}{l}\text { Approx. Chi-Square } \\
\text { Df } \\
\text { Sig. }\end{array}$ & $\begin{array}{r}8.253 \mathrm{E} 3 \\
1128 \\
.000\end{array}$ \\
\hline
\end{tabular}

\section{Scree Test Criterion:}

The scree test is derived by plotting the latent roots (eigen values) against the number of factors (component factor) in their order of extraction, and the shape of the resulting curve is used to evaluate the cutoff point. Starting with first factor, the plot slopes steeply downward initially and then slowly becomes more or less like a horizontal line. The point after which the curve first begins to straighten out is considered to indicate the maximum number of factors to extract (Hair et al, 2006). In the present case, the five factors would qualify for extraction.

Figure 1: Scree Plot

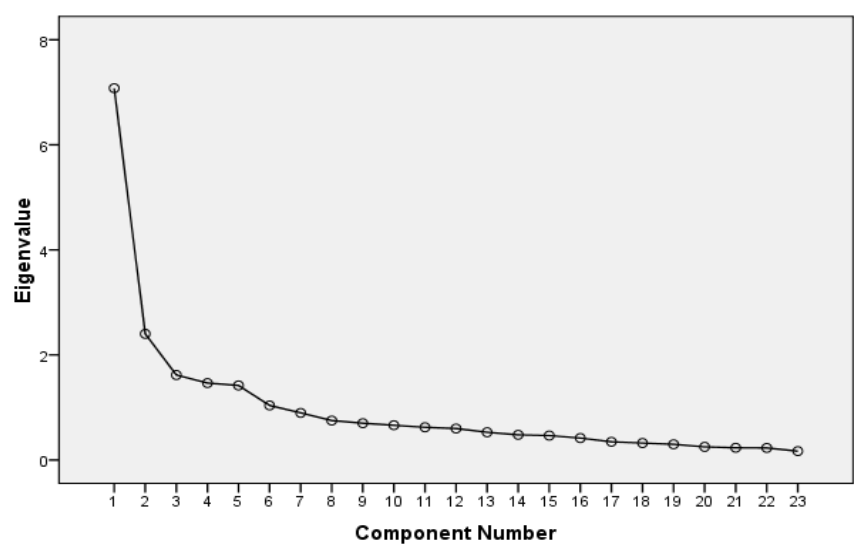

The component analysis model is most appropriate when data reduction is paramount (Hair et al, 2006). Hence, Principal Component Analysis was employed for factor extraction. The rotation of the factors improves the interpretation by reducing some of the ambiguities that often accompany initial unrotated factor solutions. Orthogonal rotation methods are the most widely used rotational methods and are the preferred method when the research goal is data reduction (Hair et al, 2006). Therefore for factor rotations, Varimax with Kaiser Normalization was used which is one of the most commonly used methods of Orthogonal rotations. In table 2, first five factors have been extracted. The eigen values of all the five factors from 1 to 5 are $7.078,2.401,1.618$, $1.465,1.420$ respectively. All these eigen values are above 1 . The percentage of variance explained is a summary measure indicating how much of the total original variance of all variables the factor represents and the percentage of variance-explained statistics can be useful in evaluating and interpreting a factor (Aaker et al., 2001). The rotation sums of squared loadings column reveal the percentage of variance explained by each 
factor. For the factors 1 to 5 the variance explained are $16.744 \%, 16.031 \%, 13.031 \%, 8.063 \%, 6.577 \%$ respectively. The cumulative total percentage variance in sales performance of retail sales people explained by these five factors is $60.794 \%$.

\begin{tabular}{|c|c|c|c|c|c|c|c|c|c|}
\hline & & & Tal & le 2: Va & iance Expla & & & & \\
\hline Component & & Initial Eigen & Values & Ext & $\begin{array}{l}\text { ction Sums } \\
\text { Loadin }\end{array}$ & f Squared & & $\begin{array}{l}\text { tion Sums } \\
\text { Loadin }\end{array}$ & $\begin{array}{l}\text { Squared } \\
\text { s }\end{array}$ \\
\hline & Total & $\begin{array}{c}\% \text { of } \\
\text { Variance }\end{array}$ & $\begin{array}{c}\text { Cumulative } \\
\%\end{array}$ & Total & $\begin{array}{c}\% \text { of } \\
\text { Variance }\end{array}$ & $\begin{array}{c}\text { Cumulative } \\
\%\end{array}$ & Total & $\begin{array}{c}\% \text { of } \\
\text { Variance }\end{array}$ & $\underset{\%}{\text { Cumulative }}$ \\
\hline 1 & 7.078 & 30.776 & 30.776 & 7.078 & 30.776 & 30.776 & 3.851 & 16.744 & 16.744 \\
\hline 2 & 2.401 & 10.439 & 41.215 & 2.401 & 10.439 & 41.215 & 3.689 & 16.031 & 32.775 \\
\hline 3 & 1.618 & 7.036 & 48.251 & 1.618 & 7.036 & 48.251 & 3.082 & 13.399 & 46.174 \\
\hline 4 & 1.465 & 6.370 & 54.621 & 1.465 & 6.370 & 54.621 & 1.855 & 8.063 & 54.237 \\
\hline 5 & 1.420 & 6.173 & 60.794 & 1.420 & 6.173 & 60.794 & 1.508 & 6.577 & 60.794 \\
\hline 6 & 1.039 & 4.517 & 65.310 & & & & & & \\
\hline 7 & .897 & 3.900 & 69.211 & & & & & & \\
\hline 8 & .752 & 3.267 & 72.478 & & & & & & \\
\hline 9 & .701 & 3.049 & 75.527 & & & & & & \\
\hline 10 & .662 & 2.877 & 78.404 & & & & & & \\
\hline 11 & .623 & 2.709 & 81.113 & & & & & & \\
\hline 12 & .600 & 2.608 & 83.721 & & & & & & \\
\hline 13 & .529 & 2.299 & 86.020 & & & & & & \\
\hline 14 & .480 & 2.086 & 88.107 & & & & & & \\
\hline 15 & .465 & 2.023 & 90.130 & & & & & & \\
\hline 16 & .417 & 1.815 & 91.945 & & & & & & \\
\hline 17 & .347 & 1.509 & 93.454 & & & & & & \\
\hline 18 & .323 & 1.406 & 94.861 & & & & & & \\
\hline 19 & .300 & 1.303 & 96.163 & & & & & & \\
\hline 20 & .250 & 1.089 & 97.252 & & & & & & \\
\hline 21 & .232 & 1.010 & 98.262 & & & & & & \\
\hline 22 & .230 & 1.000 & 99.263 & & & & & & \\
\hline 23 & .170 & .737 & 100.000 & & & & & & \\
\hline
\end{tabular}

Factor loadings are the correlation of each variable (item) and the factor. Loadings indicate the degree of correspondence between the variable and the factor, with higher loadings making the variable representative of the factor. Factor loadings are the means of interpreting the role each variable plays in defining each factor. In a sample of nearly $250 \&$ above; the factor loadings of $0.35 \&$ above are significant for consideration (Hair et al, 2006). Though thumb rule of factor analysis permit to accept loadings above 0.35 , in this study, the factor loadings of 0.40 and above are only considered (from table 3 ). Also some variables were removed which had significant loadings in more than one factor (cross loadings) and some others were removed for having low communalities. This additional care is taken to qualify only those variables which are more accurate indicators of sales performance of retail sales people. Due to the above mentioned reasons, 25 variables were removed from the analysis and then the factor analysis was again carried out by using only 23 qualified variables as inputs out of total 48 initial variables. As a result the factor loadings in this study are ranging from 0.433 to 0.774 with no cross loadings and have considerable communalities.

\begin{tabular}{|r|l|c|c|c|c|}
\hline \multicolumn{2}{|c|}{ Table: 3 Rotated Component Matrix } \\
\hline
\end{tabular}




\begin{tabular}{|r|l|l|l|l|l|l|}
\hline 7 & Satisfying the customers & 0.446 & & & \\
\hline 8 & Sales closures & & 0.774 & & & \\
\hline 9 & Sales presentations & & 0.765 & & & \\
\hline 10 & Promoting the store & & 0.756 & & & \\
\hline 11 & Moving profitable products & & 0.582 & & & \\
\hline 13 & Cross-selling \& up-selling (add on sales) & & 0.492 & & & \\
\hline 14 & Preventing stock shrinkage & & & & \\
\hline 15 & Knowledge of store policy & & 0.671 & & \\
\hline 16 & Product/Merchandise displaying & & & 0.644 & & \\
\hline 17 & Maintaining sales records & & & 0.564 & & \\
\hline 18 & Receiving \& maintaining the stock & & & 0.498 & & \\
\hline 19 & Assisting customers to find products & & & 0.433 & & \\
\hline 20 & Product demonstrations & & & & 0.717 & \\
\hline 21 & Product knowledge & & & & 0.528 & \\
\hline 22 & Assisting other sales people & & & & 0.483 & \\
\hline 23 & Maintaining relationship with manager & & & & & 0.734 \\
\hline Extraction Method: Principal Component Analysis. & & & & & 0.632 \\
\hline Rotation Method: Varimax with Kaiser Normalization. & & & & \\
\hline
\end{tabular}

Naming the Factors:

VII. Results And Discussion

When an acceptable factor solution has been obtained, it is important to assign some meaning to the pattern of factor loadings. Variables with higher loadings are considered more important and have greater influence on the name or label selected to represent the factor. Based on the grouping of variables and factor loadings, all the five factors have been named accordingly. The names of factors, the variables, and their explained variance have been summarized in table 4 .

\section{Factor 1: Customer Service}

This has emerged as the most important factor explaining $16.744 \%$ out of the total variance. It consists of variables such as adapting to customers and selling, handling customer complaints and objections, equality in treating customers, maintaining customer relationships, solving customer problems, retaining existing customers, and satisfying the customers. This dimension evaluates the customer service skills of the retail sales personnel. This is very important dimension as customer service is very important in retailing as repeat purchases happen in this industry and so giving great shopping experiences to their customers is very important.

\section{Factor 2: Sales Enhancement Ability}

The second factor explains $13.031 \%$ out of the total variance. This factor consists of variables such as sales closures, sales presentations, promoting the store, moving profitable products, cross-selling and up-selling (add on sales), and reaching sales targets. This dimension evaluates the total sales ability or the selling ability of the retail sales personnel. All these variables are directly linked to sales performance of the entire retail store but these cannot be taken as the only variables to evaluate sales performance of retail sales personnel as these variables are also the outcomes of environmental and situational influences other than sales person's effort. Hence other dimensions should also be considered while evaluating the sales performance of retail sales personnel.

\section{Factor 3: Store Management Ability}

The third factor explains $13.339 \%$ out of the total variance. This factor consists of variables such as preventing stock shrinkage, knowledge of store policy, product/merchandise displaying, maintaining sales records, and receiving the stock. This dimension evaluates the total ability of retail sales personnel to manage the store. All these tasks are also important for the sales person to realize sales. Until and unless the sales person keeps his part of retail area neat and tidy; maintain sales records, maintain proper stocks; display them properly etc, the sales person will not be able to attract his customers and attain sales. 


\section{Factor 4: Product Knowledge \& Presentation}

The fourth factor explains $8.063 \%$ out of the total variance. This factor consists of variables such as assisting customers to find products, product demonstrations, and product knowledge. This dimension evaluates the sales person's product knowledge and his ability to use the same knowledge in assisting the customers and to make better product demonstrations to influence customer purchase decisions.

\section{Factor 5: Team Work}

The last factor accounts for $6.577 \%$ out of the total variance. This factor consists of variables such as assisting other sales people, and maintaining relationship with managers. This dimension evaluates the sales person's willingness to voluntarily help other sales people to discharge their responsibility and at the same time sales person can get some help from others to accomplish his own tasks. By maintaining better relationships with the managers the sales person can get better support from his managers to carry out his everyday tasks in a smooth and efficient manner.

\begin{tabular}{|c|c|c|c|c|c|}
\hline \multicolumn{6}{|c|}{ Table 4: Naming of Factors } \\
\hline $\begin{array}{c}\text { Factor } \\
\text { Number }\end{array}$ & Name of Dimension & Variables & Loadings & $\begin{array}{c}\text { Percentage } \\
\text { of Variance } \\
\text { Explained }\end{array}$ & $\begin{array}{l}\text { Cumulative } \\
\text { percentage } \\
\text { of Variance } \\
\text { Explained }\end{array}$ \\
\hline \multirow{7}{*}{ Factor 1} & \multirow{7}{*}{ Customer Service } & Adapting to customers and selling & 0.713 & \multirow{7}{*}{16.744} & \multirow{7}{*}{16.744} \\
\hline & & $\begin{array}{l}\text { Handling customer } \\
\text { complaints/objections }\end{array}$ & 0.659 & & \\
\hline & & Equality in treating all customers & 0.657 & & \\
\hline & & Maintaining customer relationship & 0.586 & & \\
\hline & & Solving customer problems & 0.546 & & \\
\hline & & Retaining existing customers & 0.471 & & \\
\hline & & Satisfying the customers & 0.446 & & \\
\hline \multirow{6}{*}{ Factor 2} & \multirow{6}{*}{$\begin{array}{c}\text { Sales Enhancement } \\
\text { Ability }\end{array}$} & Sales closures & 0.774 & \multirow{6}{*}{16.031} & \multirow{6}{*}{32.775} \\
\hline & & Sales presentations & 0.765 & & \\
\hline & & Promoting the store & 0.756 & & \\
\hline & & Moving profitable products & 0.582 & & \\
\hline & & $\begin{array}{l}\text { Cross-selling \& up-selling (add on } \\
\text { sales) }\end{array}$ & 0.492 & & \\
\hline & & Reaching sales targets & 0.461 & & \\
\hline \multirow{5}{*}{ Factor 3} & \multirow{5}{*}{$\begin{array}{c}\text { Store Management } \\
\text { Ability }\end{array}$} & Preventing stock shrinkage & 0.677 & \multirow{5}{*}{13.339} & \multirow{5}{*}{46.174} \\
\hline & & Knowledge of store policy & 0.644 & & \\
\hline & & Product/Merchandise displaying & 0.564 & & \\
\hline & & Maintaining sales records & 0.498 & & \\
\hline & & Receiving \& maintaining the stock & 0.433 & & \\
\hline \multirow{3}{*}{ Factor 4} & \multirow{3}{*}{$\begin{array}{l}\text { Product Knowledge } \\
\text { \& Presentation }\end{array}$} & Assisting customers to find products & 0.717 & \multirow{3}{*}{8.063} & \multirow{3}{*}{54.237} \\
\hline & & Product demonstrations & 0.528 & & \\
\hline & & Product knowledge & 0.483 & & \\
\hline \multirow[b]{2}{*}{ Factor 5} & \multirow[b]{2}{*}{ Team Work } & Assisting other sales people & 0.734 & \multirow[b]{2}{*}{6.577} & \multirow[b]{2}{*}{60.794} \\
\hline & & $\begin{array}{l}\text { Maintaining relationship with } \\
\text { manager }\end{array}$ & 0.632 & & \\
\hline
\end{tabular}

\section{Reliability:}

To measure reliability of the scale, inter-item consistency reliability test is used. It is a test of consistency of responses to all the items in a measure (Sekaran and Bougie, 2010). The most popular test of inter-item consistency reliability is Cronbach's coefficient alpha (Cronbach, 1946). Nunnally (1978) has given the guideline for analysing Cronbach's alpha. The guideline says that alpha between 0.5 to 0.6 for exploratory research can be considered. Nonetheless, Peter (1979) has even suggested that reliability levels of less than 0.5 may also be acceptable in marketing research. However, the Cronbach's alpha for all the dimensions are above 0.60 hence reliability exists among all the dimensions in the measurement scale.

\begin{tabular}{|c|c|c|}
\hline \multicolumn{3}{|c|}{ Table 5: Reliability Analysis } \\
\hline Name of the Dimension & No of Items & 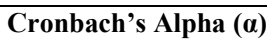 \\
\hline Customer Service & 7 & 0.850 \\
\hline Sales Enhancement Ability & 6 & 0.824 \\
\hline Store Management Ability & 5 & 0.745 \\
\hline
\end{tabular}




\begin{tabular}{|l|l|l|}
\hline Product Knowledge \& Presentation & 3 & 0.682 \\
\hline Team Work & 2 & 0.643 \\
\hline
\end{tabular}

\section{Validity:}

Validity is a test of how well an instrument that is developed measures the particular concept it is measuring and it is the most critical criterion (Sekaran and Bougie, 2010; Kothari, 2004). Here in this case content validity has been used to check the validity of the scale. Content validity is the assessment of the correspondence of the variables to be included in a summated scale. This form of validity is also known as face validity (Hair et al, 2006). The objective is to ensure that the genuineness of scale items is done by including some theoretical and practical considerations rather than just doing it empirically (Churchill, 1979). It subjectively assesses the correspondence between the individual items and the concept through ratings by expert judges, pretests with multiple sub populations, or other means. Hence the researcher always subjectively evaluates it. The content validity of the variables or scale items was done based on the literature review and also based on the opinions of several experts like sales managers, sales personnel, HR professionals in retail stores and by some faculty experts in marketing. Therefore, the items in the sales performance scale conforms the content validity.

\section{Conclusion}

In the present study, five sales performance dimensions have been found and a subjective multidimensional scale for measuring sales performance of retail sales people has been developed empirically.

The final version of this instrument consists of 23 items or variables that represent five dimensions of retail sales performance namely (a) Customer Service, (b) Sales Enhancement Ability, (c) Store Management Ability, (d) Product Knowledge and Presentation, and Team Work. This scale is designed for self-reporting or immediate supervisor-reporting based on the need of the study. A five point rating scale has to be used to collect the responses either from sales persons or by their immediate supervisor and managers. The responses to be collected in this 5-point scale format where 5 is "Outstanding", 4 is "Above Average", 3 is "Average", 2 is "Below Average", and 1 is "Poor". The item scores are summed within factors to form factor scores. Also the sum of overall items can be taken to form overall retail sales force performance score.

This scale bridges the gap of a perfect standardised scale which was required to evaluate the sales performance of retail salespeople in a subjective way as objective evaluation of the retail sales staff does not consider all key areas of their job which are necessary for them to attain sales. It covers almost all dimensions of a retail sales person's job. This scale can be used by both researchers and sales managers to evaluate the sales performance of retail salespeople. The scale can be used for any organized retail formats and only the bigger unorganized retail formats. Future researchers can also focus on applying this scale on many different formats of retailing, which will help to validate its applications and generalize the scale's usability.

\section{References:}

[1]. Aaker, J.L., Benet-Martinez, V., and Garolera, J., Consumption Symbols as Carriers of Culture: A Study of Japanese and Spanish Brand Personality Constructs, Journal of Personality and Social Psychology, 81(3), 2001, 492-508.

[2]. Abelson, M.A., Kacmar, K.M., and Jackofsky E.F., Factors Influencing Real Estate Brokerage Sales Staff Performance, The Journal of Real Estate Research, 5(2), 1990, 265-275.

[3]. Ahmad, N., Kamariah Nik Mat, N., Mohamed Isa, M. F., Ismail, S., Amlus, M. H., An Analysis of Alternative Causal Models of Sales Performance on Sales People, American Journal of Economics, June, Special Issue, 2012, 101-104.

[4]. Behrman, D. N., and Perreault, W. D., Measuring the Performance of Industrial Salespersons, Journal of Business Research, 10(3), 1982, 355-370.

[5]. Bush, A.J., Bush, P.A., Ortinau, D.J., and Hair, J.F., Developing a Behaviour-Based Scale to Assess Retail Salesperson Performance, Journal of Retailing, 66, 1990, 119-129.

[6]. Campbell, J.P., Modelling the Performance Prediction Problem in Industrial and Organization Psychology in Marvin D. Dunnette and Leaetta Hough (eds.), Handbook of Industrial and Organizational Psychology, 2, 1990, 687-732.

[7]. Chonko, L.B., Loe, T.N., Roberts, J.A., and Tanner, J.F., Sales Performance: Timing of Measurement and Type of Measurement Make a Difference, The Journal of Personal Selling and Sales Management, 20(1), 2000, 23-36.

[8]. Churchill, G.A., A Paradigm for Developing Better Measures of Marketing Constructs, Journal of Marketing Research, 16(February), 1979, 64-73.

[9]. Colletti, J. and Tubridy, G., Reinventing the Sales Organization (Scottsdale, AZ: Alexander Group, 1993).

[10]. Cronbach, L.J., Response Sets and Test Validating, Educational and Psychological Measurement, 6, 1946, 475-494.

[11]. Dalrymple, D., Cron, W., and Decarlo, T., Sales Management ( $8^{\text {th }}$ Edition, New Jersey, Wiley, 2004).

[12]. Damnjanovic, V., and Kulj, D., Important Factors for Salesperson Evaluation, Paper Presented at the The 7th Balkan Conference on Operational Research, BACOR 05, Constanta, May 2005, Romania.

[13]. Fitzgerald, L., Moon, P., Performance Measurement in Service Industries: Making It Work (CIMA, London, 1996).

[14]. Futrell, M. C., Sales Management, Teamwork, Leadership and Technology (The Dryen Press, pp: 635, 1998).

[15]. Hair, Jr. J.F., Black, W.C., Babin, B.J., Anderson, R.E., and Tatham, R.L., Multivariate Data Analysis (Sixth Edition, Pearson Education, New Delhi, India, 2006).

[16]. Johlke, M. C., Duhan, D. F., Howell, R. D., \& Wilkes, R. W., An Integrated Model of Sales Managers' Communication Practices, Journal of the Academy of Marketing Science, 28(2), 2000, 63-277.

[17]. John, A.G., Francis, A.I., and Innocent, C.I., Improving Sales Performance through Sales Force Motivation Strategies: A Study of Pharmaceutical Firms in Nigeria, International Journal of Business Management, Economics Research, 3(5), 2012, 620-626.

[18]. Kohli, A., and Jaworski, R., The Influence of Co-worker Feedback on Salespeople, Journal of Marketing, 58 (October), $1994,82-94$. 
[19]. Komaran, R.V., and Ching, T.L., Sales Force Evaluation by Local and Foreign Wholesale Companies in Singapore, Asian Academy of Management Journal, 2(1\&2), 1997, 71-91.

[20]. Kothari, C.R., Research Methodology: Methods and Techniques (Second Revised Edition, New Age International Publishers, New Delhi, pp: 69-94, 2004)

[21]. Ma, C. M., Yu, C.T., and Cheng, B.W., An Integrative Framework among Automobile Salespeople Personality, Learning and Sales Performance, Journal of Applied Sciences, 13(8), 2013, 1177-1184.

[22]. Malhotra, N.K., and Dash, S., Market Research-An Applied Orientation (Fifth Edition, Pearson Education, New Delhi, India, pp: 610-635, 2007)

[23]. Nargundkar, R., Marketing Research (Third Edition, Tata McGraw-Hill, New Delhi, India, pp. 326-347, 2008).

[24]. Nunnally, J, C., Psychometric Theory (Second Edition, McGraw-Hill, New York, 1978).

[25]. Peter, J. Paul, Reliability: A Review of Psychographic Basics and Recent Marketing Practices, Journal of Marketing Research, 16(2), 1979, 6-17.

[26]. Pettijohn, C. E., Pettijohn, L.S., Taylor, A.J., and Keillor, B. D., Adaptive Selling and Sales Performance: An Empirical Examination, The Journal of Applied Business Research", 16(1), 2000, 91-111.

[27]. Pilling, M.E., Donthu, N., and Henson, S., Accounting for the Impact of Territory Characteristics on Sales Performance: Relative Efficiency as a Measure of Salesperson Performance, Journal of Personal Selling and Sales Management, 19, 1999, $35-45$.

[28]. Plouffe C. R., Sridharan, S., and Barclay, D. W., Exploratory Navigation and Salesperson Performance: Investigating Selected Antecedents and Boundary Conditions in High-Technology and Financial Services Contexts, Industrial Marketing Management, 39, 2010, 538-550.

[29]. Porter, M.E., Competitive Advantage ( $1^{\text {st }}$ Edition, Free Press, New York, 1985).

[30]. Salleh, F.T., and Kamaruddin, A.Z.B., The Effects of Personality Factors on Sales Performance of Takaful (Islamic Insurance) Agents in Malaysia, International Journal of Business and Social Science, 2(5), 2011, 259-265.

[31]. Samad, K.B., and Jainullabdeen, A., Impact of Selling Behaviours on Sales Performance of Prescription Drugs, Paripex-Indian Journal of Research, 2(10), 2013, 113-116.

[32]. Sekaran, U., and Bougie, R., Research Methods for Business: A Skill Building Approach (Fifth Edition, Wiley India, New Delhi, pp: 139-166, 2010). 